\title{
AUSTRALIA'S GAAR TURNS 40: IN ITS PRIME OR MID-LIFE CRISIS?
}

\author{
Miranda Stewart
}

This article explores aspects of the legislative evolution of Australia's general anti-avoidance rule (GAAR) in pt IVA of the Income Tax Assessment Act 1936 (ITAA36) and considers how it shapes up after 40 years. It considers the legislative interaction of the GAAR with other parts of the income tax statute and explores the GAAR in an international context, including the Multinational AntiAvoidance Law (MAAL) and Diverted Profits Tax (DPT) inserted into pt IVA. It concludes with consideration of the role and legitimacy of the GAAR in respect of both domestic and international economic and legal transactions.

\section{INTRODUCTION}

The year 2021 marks 40 years since the commencement of Australia's GAAR in pt IVA of the Income Tax Assessment Act 1936 (ITAA36). ${ }^{1}$ The GAAR has been extensively considered by the courts since its introduction in 1981. Amendments in 2013 sought to strengthen it and override the judicial interpretation of tax benefit; these amendments have not yet been tested in the courts. At the same time, in a unilateral action taken by Australia at the start of the G20-OECD Base Erosion and Profit Shifting (BEPS) project, the GAAR was amended to extend it to tax avoidance by large multinational enterprises (MNEs). This was done by introducing the Multinational Anti-Avoidance Law (MAAL) and the Diverted Profits Tax (DPT) into pt IVA.

In addition to the GAAR, as is the case for the income tax law of most other countries, Australia's income tax law contains numerous targeted anti-avoidance rules (TAARs) designed to address particular transactions or arrangements. For example, Div 7A ITAA36 treats private company benefits as deemed dividends and pt 2-42 Income Tax Assessment Act 1997 (ITAA97) treats income from personal services of an individual as assessable income of that individual where it is derived as income by a company or trust and is not promptly paid out as salary. Many TAARs address international tax

* Professor, Melbourne Law School; m.stewart@unimelb.edu.au.

1 This article draws in part on Sarah Blakelock and Miranda Stewart "Australia's Evolving General AntiAvoidance Law" in M Tron (ed) The Structure of Anti-Avoidance Rules Vol 100a Cahiers de droit fiscal international (70th IFA Congress, Sdu Fiscale \& Financiele Uitgevers, The Netherlands, 2018). 
planning. Australia's transfer pricing rules in Div 815 ITAA97, thin capitalisation rules in Div 820 and controlled foreign company rules in pt $\mathrm{X}$ of the ITAA36 are important examples. The GAAR, including the recent BEPS extensions, takes precedence over all other provisions in the income tax law and over Australia's bilateral and multilateral tax treaties. It is usually applied as a last resort, but this is by convention rather than legislative requirement.

This essay explores some aspects of the legislative evolution of Australia's GAAR and considers how it shapes up after 40 years. The essay considers the legislative "fit" or interaction of the GAAR with other parts of the income tax statute and with economic and legal transactions more generally. It then turns to explore the GAAR in an international context, both in its general operation and through application of the MAAL and DPT. I conclude with consideration of the role, legitimacy and effectiveness of the GAAR in respect of both domestic and international legal and economic transactions.

\section{EVOLUTION OF THE GAAR IN AUSTRALIA}

\section{A Legislative Evolution}

Australia has had a legislative GAAR in the federal income tax since its inception in 1915. The three main legislative enactments of the GAAR over the last century indicate an evolution in thinking (and drafting) about the role and function of the GAAR. The first federal GAAR in s 53 of the Income Tax Act 1915 (Cth), referred to tax avoidance in the older judicial language of sham and evasion. In Jaques $v F C T^{2}$ the High Court construed s 53 with reference to what the court already knew of these concepts. The case concerned a scheme to convert an existing company into two new companies. The new companies contracted with the shareholders of the old company to contribute capital by responding to a call for shares. This generated a tax deduction for the shareholders and saved stamp duty on the transaction. The Commissioner argued in the alternative that (1) the transaction was a sham, (2) it was an evasion of the tax law and (3) it was a breach of the GAAR. The taxpayer responded that the GAAR was merely a statutory enactment of the sham doctrine; this meant that the transaction had to be "unreal, colourable or concealed", a threshold of deception that it claimed was not met in this case. At first instance, Rich J found for the Commissioner, stating: ${ }^{3}$

Numerous judicial decisions have dealt with the subject of sham transactions and transactions said to be 'evasions' of the law. There is always great difficulty in determining in any particular case whether a transaction is a lawful or unlawful 'evasion' of a statute. I apprehend that the Commonwealth Parliament, in passing sec. 53, recognized the difficulties I have referred to and determined to get away from them. It laid down its own test of avoidance for its own purposes. Therefore, what I have to do is not to consider the question of 'evasion' by the light of the standard authorities on that subject. Nor do I see on the facts

2 Jaques v FCT (1923-1924) 34 CLR 328 (HCA).

3 At 338 
before me how I can treat what has been done as an unreality. Sec. 53 regards the 'contract, agreement, or arrangement' as possibly a very real one, but attaches consequences to the purpose or effect.

The full Court upheld the decision of Rich J. Knox CJ somewhat ambiguously concluded that the transactions "were in no sense real genuine transactions, but were devised and carried out in order to conceal the true nature of the real agreements between the parties," 4 being entered into "to enable the members of the old company to escape wholly or in part from their liability to pay income tax on their true taxable income". 5 In separate judgments, Isaacs and Starke JJ each applied the GAAR despite accepting that the transactions were legally "genuine". Isaacs J said that the "reality" of the transaction at law: 6

includes the complete individual distinctness of the new companies from the old company. [...] complete according to State law, which governs these transactions. [...] But then comes the Federal income tax law ... That the transaction is a reality is no reason for the non-application of [the GAAR]. On the contrary, if the transaction were not real and effective apart from the section, that section would be unnecessary. A sham transaction is inherently worthless, and needs no enactment to nullify it.

However, this strong start for the GAAR was not carried through in subsequent cases in which the Commissioner attempted to apply s 53, leading to its replacement in s 260 of ITAA36. Both s 53 and its replacement in s 260 of ITAA36 adopted the language that a transaction found to breach the GAAR is "absolutely void as against the Commissioner". However, s 260 moved away from the language of evasion towards concepts of purpose and abuse.

Section 260 was drafted in wide terms and the judiciary may have reacted with an excessively narrow or technical interpretation. There was concern that, if construed literally, s 260 could extend to almost every tax-related transaction that took place in the community and "this conundrum bedevilled s 260". ${ }^{7}$ Initially, the so-called "predication" test proposed in Newton's case prevailed. ${ }^{8}$ Lord Denning in the Privy Council explained this approach to applying s $260{ }^{9}$

In order to bring the arrangement within the section you must be able to predicate - by looking at the overt acts by which it was implemented - that it was implemented in that particular way so as to avoid tax. If you cannot so predicate, but have to acknowledge that the transactions are capable of explanation by

4 At 355

5 At 355

6 At $357-358$

7 Australian Tax Office Practice Statement PS LA 2005/24, Attachment 2: Tax Office Comments on the Operation of Part IVA (13 December 2005); see Anthony Portas Part IVA: Dominant Purpose - An Analysis of the Eight Factors (Queensland Tax Forum, 2016) at 11.

8 Newton v FCT (1958) 98 CLR 1 (PC).

9 At 9 . 
reference to ordinary business or family dealing, without necessarily being labelled as a means to avoid tax, then the arrangement does not come within the section.

The 1970s saw an apparently unprecedented adoption of tax avoidance schemes by a wide range of taxpayers, some of which crossed the line to tax evasion, such as the "bottom of the harbour" tax schemes. These tax schemes were fuelled by high individual and corporate tax rates; the non-taxation of capital gains; the territorial boundaries of Australia's source-based tax jurisdiction; and the "double taxation" of corporate profits. A further factor was the increasing ease of access for individual and corporate taxpayers to tax havens which were conveniently close by in the Pacific, including the Cook Islands and Vanuatu, while drawing on international tax planning expertise from Australia's major trading partners in the United States and United Kingdom. Tax avoidance was also fostered by an excessively narrow interpretation of s 260 by the courts. ${ }^{10}$ It has been suggested that the approach in Newton was supplanted in Australia by an even more narrow "choice" principle. ${ }^{11}$ The deficiencies in s 260 were of increasing concern to the Commissioner, after a series of attempts to apply it failed. ${ }^{12}$

The modern rule legislated in pt IVA in 1981 again broke with the past. Australia may have been the first country to adopt a GAAR that broke down the inquiry into separate elements of scheme, tax benefit, and an objective sole or dominant purpose test. Where a tax benefit is found in connection with a scheme to which the GAAR applies, and the purpose threshold is met, the Commissioner has the power to make a determination to cancel all or part of the tax benefit, and to take any action necessary to give effect to that determination. ${ }^{13}$ To give effect to any determination, the Commissioner is required to issue an amended assessment. ${ }^{14}$ The Commissioner may also make compensating adjustments relating to other taxpayers. ${ }^{15}$

The replacement of s 260 with pt IVA was aimed at cracking down on the most extreme tax avoidance. The Liberal-National (conservative) government which replaced s 260 with pt IVA was

10 Trevor Boucher Blatant, Artificial and Contrived: Tax Schemes of the 70s and 80s (Australian Tax Office, 2010); and Arie Freiburg "Ripples from the Bottom of the Harbour: Some Social Ramifications of Taxation Fraud" (1998) 12 Criminal L J at 136

11 G T Pagone "Part IVA: The General Anti-Avoidance Provisions in Australian Taxation Law" (2003) 27 MULR 770.

12 See for example Cridland v FCT (1977) 140 CLR 330 (HCA); Slutzkin v FCT (1977) 7 ATR 166 (HCA); Patcorp Investments Ltd v FCT (1976) 10 ALR 407 (HCA); and Mullens v FCT (1976) 6 ATR 504 (HCA).

13 ITAA36, s 177F(1)

14 FCT v Jackson (1990) 27 FCR 1 (FCA). However, the Commissioner is not required to issue an amended assessment to the taxpayer who obtains the tax benefit: Grollo Nominees Pty Ltd v FCT (1997) 73 FCR 452 (FCA).

15 ITAA36, s 177F(3). 
convinced that something had to be done but the anxiety about what would come within the reformulated GAAR was revealed in Treasurer John Howard's Second Reading speech: ${ }^{16}$

We are acutely aware that 'tax avoidance' means different things to different people. Reasonable men and women are bound to differ on this crucial question and on the subsidiary matter of the appropriate tests for determining what behaviour a general anti-avoidance rule ought to proscribe [...]. The proposed provisions ... seek to give effect to a policy that such measures ought to strike down blatant, artificial or contrived arrangements, but not cast unnecessary inhibitions on normal commercial transactions by which taxpayers legitimately take advantage of opportunities available for the arrangement of their affairs.

The Explanatory Memorandum to the Bill introducing pt IVA indicates that the approach of the Privy Council in Newton's case was influential. ${ }^{17}$ It is interesting to consider whether the drafting and structure of pt IVA, and subsequent judicial approach to it, has detached the analysis entirely from the "predication" test, in contrast to the New Zealand GAAR which retains its previous structure. ${ }^{18}$

It was hoped that the re-draft would survive the supposed "assassination" of previous versions by the courts. ${ }^{19}$ With hindsight, it is possible that a more moderate judicial approach could have addressed some of the concerns as during the 1980s, after pt IVA was enacted, the courts applied the former s 260 to strike down various avoidance arrangements still subject to the earlier rule. ${ }^{20}$ However, these subsequent judicial approaches to s 260 were also the subject of criticism. ${ }^{21}$

\section{$B$ Distinguishing the GAAR from Sham or a Realistic View of the Facts}

The High Court rejected the application of a judicial anti-abuse doctrine in Australia (as had been developed in the United Kingdom) because of the existence of the statutory GAAR. ${ }^{22}$ However, the courts have always had at their disposal a doctrine of sham. Moreover, at least since the 1980 s, the

16 (27 May 1981) AUPD HR 123 at 2683.

17 Newton v Federal Commissioner of Taxation, above n 8; see Income Tax Laws Amendment Bill (No 2) 1981 (Cth) (explanatory memorandum) at 3.

18 And its reliance on the "predication" test; the NZ GAAR seems nonetheless to be reasonably effective in responding to tax avoidance schemes. See John Prebble and Hamish McIntosh "Predication: The test for tax avoidance in New Zealand from Newton to Ben Nevis" (2015) 46 VUWLR 1011.

19 Peter Clyne New Tax Dodger's Dictionary, or, How to out-bluff, out-hassle and out-litigate the fiscal fiend from A to Z (Cassell Australia, Australia, 1981).

20 See for example Tupicoff $v$ FCT (1984) 4 FCR 505 (FCAFC).

21 Robin Speed "The High Court and Part IVA" (1986) 15 AT Rev 156, as cited in GT Pagone Tax Avoidance in Australia (The Federation Press, Sydney, 2010) at 37; and ICF Spry "The New Approach by the High Court on Section 260" (1986) 15 AT Rev 1.

22 John v FCT (1989) 166 CLR 417 (HCA), rejecting the application of the House of Lords' approach developed in WT Ramsay Ltd v Inland Revenue Commissioners [1982] AC 300 (HL); and Inland Revenue Comrs v Burmah Oil Co Ltd (1981) 54 TC 200 (HL); and Furniss v Dawson [1984] AC 474 (HL). 
courts have applied a purposive approach to statutory interpretation and have often explicitly taken a realistic and commercial view of the facts, including the purpose of the taxpayer. Today, Australian courts do not often take a formalistic approach to legal or economic facts, despite the suggestion by David Bloom QC that "in the absence of the application of the anti-avoidance provisions, the need to respect form over substance, is, in Australia, very much alive". ${ }^{23}$ The "realistic" approach to the facts has helped to secure stability of the income tax law without resort to the GAAR.

For example, in respect of the general deduction rule in s 8-1 of ITAA97, the High Court has stated that where a "dual", "other" or "colourable" purpose of incurring an expense is identified, and assessable income is not generated in excess of the expense, then the purpose of gaining or producing assessable income may not be made out and the deduction may be limited or denied. ${ }^{24}$ In Vincent $v$ $F C T,{ }^{25}$ a test case of importance for the mass marketed schemes of the 1990 s, concerning whether several hundred participants in a cattle scheme were able to claim deductions, the Full Court of the Federal Court concluded that Ms Vincent was not in a "business" of cattle farming and therefore could not claim deductions. ${ }^{26}$

In the international context, a "realistic" view of the facts was applied to determine the residence of a corporation in Bywater Investments Ltd v FCT. ${ }^{27}$ The High Court affirmed a finding that directors' meetings and other documentation relating to several companies were "fake" and intended to create an appearance of corporate residence in a tax haven. A realistic view of the facts found that control and management of the company was held by a single person in Sydney, and hence, corporate residence was in Australia.

The judicial doctrine of sham is stronger but is more rarely applied by the courts. It requires a finding of an intention to deceive the revenue concerning the true character of the legal facts, or the true construction of the legal transaction between the parties. ${ }^{28}$ Where a sham is found, the transaction is void and the tax law is applied to the "true" legal transaction as identified by a court. The doctrine

23 David Bloom "Tax Avoidance-A View From The Dark Side" (5 August 2015) The University of Melbourne <law.unimelb.edu.au> at 25.

24 Ure v FCT (1981) 50 FCR 219 (FCAFC); and Fletcher v FCT [1991] HCA 42, (1991) 173 CLR 1.

25 Vincent $v$ Commissioner of Taxation (2002) 124 FCR 350 (FCAFC).

26 Vincent $v$ Commissioner of Taxation, above $\mathrm{n} 25$.

27 Bywater Investments Ltd v Commissioner of Taxation (2015) 236 FCR 520 (FCA).

28 For a detailed analysis see Miranda Stewart "The judicial doctrine in Australia" in Edward Simpson and Miranda Stewart (eds) Sham Transactions (Oxford University Press, Oxford, 2013) 51; GT Pagone "Sham Trusts" (2012) 41 AT Rev 119; Michael Kirby "Of Sham and Other Lessons for Australian Revenue Law" (2008) 32 MULR 27; Tony Slater "Sham and Substance" (1999) 28 AT Rev 197; and John Glover "Sham, Raftland and the Return of Economic Equivalence" (2008) 43 TIA 21. 
was affirmed by the High Court in Raftland Pty Ltd $v F C T^{29}$ in which legal arrangements relating to a trust engaged in loss trading were held to be a sham.

Courts in Australia and New Zealand have had to analyse the relationship between "sham" and the GAAR; in Australia, the issue arose in Jaques, discussed above, relating to the first legislative GAAR. ${ }^{30}$ The doctrine of sham has occasionally been applied in Australia to nullify tax avoidance schemes, ${ }^{31}$ but Australian judges have emphasised that the presence of markers of tax avoidance including circularity of transactions; use of nonrecourse debt; and complexity or artificiality of transactions and legal entities do not necessarily indicate a sham. ${ }^{32}$ In New Zealand, courts have considered both the doctrine of sham and the GAAR (currently in s BG1 of Income Tax Act 2007 $(\mathrm{NZ})$ ) in numerous cases and have held that a sham exists where the transaction or document is a mask, cloak, or façade concealing the true position between the parties. ${ }^{33}$ The New Zealand Supreme Court affirmed in Ben Nevis Forestry Ventures Ltd v Commissioner of Inland Revenue that: ${ }^{34}$

a document will be a sham when it does not evidence the true common intention of the parties. [...] designed to lead the taxation authorities to view the documentation as representing what the parties have agreed when it does not record their true agreement.

Griffiths and Palmer identify significant confusion in New Zealand cases about the doctrine of sham, the concept of economic substance and the application of the GAAR. ${ }^{35}$

The doctrine of sham is applied at an earlier stage of analysis than a statutory GAAR because it concerns the legal effect and not the economic effect of the transaction based on evidence of the true legal intention of the parties. ${ }^{36}$ It performs the important though limited function of rescuing the judge

29 Raftland Pty Ltd v FCT (2008) 238 CLR 516 (HCA).

30 Jaques $v F C T$, above $\mathrm{n} 2$.

31 Sharrment Pty Ltd v Official Trustee in Bankruptcy (1988) 82 ALR 530 (FCA) at 536 per Lockhart J; and Raftland Pty Ltd v FCT (2008) 238 CLR 516 (HCA).

32 Sharrment Pty Ltd v Official Trustee in Bankruptcy, above n 31, at 536.

33 See for example Bateman Television Ltd v Coleridge Finance Co Ltd [1969] NZLR 794 (CA), affirmed on appeal: Bateman Television Ltd v Coleridge Finance Co Ltd [1971] NZLR 929 (PC); Paintin and Nottingham Ltd v Miller Gale and Winter [1971] NZLR 164 (CA); Re Securitibank Ltd (No 2) [1978] 2 NZLR 136 (CA); and Marac Finance Ltd v Virtue [1981] 1 NZLR 586 (CA)

34 Ben Nevis Forestry Ventures Ltd v CIR [2008] NZSC 115 at [33].

35 Shelley Griffiths and Jessica Palmer "Sham, Tax Avoidance and a GAAR: A New Zealand Perspective" in Simpson and Stewart (eds) Sham Transactions (Oxford University Press, Oxford, 2013) 228 at 228; and David McLauchlan "Agreements to Buy One's Own Goods - Implied Preceding Sale or Sham?" (1995) 1 NZBLQ 21.

36 Raftland Pty Ltd v FCT (2006) 62 ATR 49 (FCA) at [79] and [89]. 
"from being led by the nose". ${ }^{37}$ This protects taxation law by ensuring that the rules for construing legal transactions are properly applied and it protects these rules from deceit, bad faith or fraudulent intent. In this way, the doctrine is a companion to the purposive interpretation of tax law with reference to its policy.

Despite these various types of judicial anti-abuse approach, the courts have legitimated some forms of tax minimisation as essentially structural features of the income tax law. This applies in particular to income splitting by taxpayers in professional practices, and by business and investment owners. ${ }^{38}$ For example, income splitting through a service trust for a professional firm is acceptable, and the constraint of a "commercially realistic" fee is not particularly onerous. ${ }^{39} \mathrm{It}$ is usually assumed that the GAAR would not apply to these "ordinary business or family dealings". Similarly, Everett assignments continue to fall on the "right side" of the tracks laid by the GAAR in Australia, although this is currently subject to some controversy, as the ATO has paid increasing attention to more extreme versions of professional firm structures in recent years. ${ }^{40}$

\section{THE GAAR IN THE CONTEXT OF THE INCOME TAX STATUTE}

\section{A A Holistic View of the GAAR}

There are two aspects to a holistic view of the GAAR in the context of the income tax statute. The first concerns the relationship of the GAAR with the other rules in the ITAA36 and ITAA97. The second concerns the interpretation of the GAAR itself as an integrated whole. All of the separate requirements of pt IVA are interconnected, so a scheme entered into with the sole or dominant purpose of obtaining the tax benefit connected with the scheme is the "pivot" or "fulcrum" on which the GAAR is said to operate. ${ }^{41}$ To ascertain this, the GAAR is premised on a hypothetical inquiry into the scheme, purpose and tax benefit compared to a counterfactual of what would otherwise have been done by the taxpayer. This integrated approach suggests that there is a legislative purity to the structure of the GAAR in the statute which should be preserved. ${ }^{42}$

37 Raftland Pty Ltd v FCT, above n 29, at [151] per Kirby J.

38 FCT v Everett (1978) 38 FLR 26 (FCA) (Deane J dissenting), affirmed in FCT v Everett (1980) 143 CLR 440 (HCA); and FCT v Phillips (1978) 36 FLR 399 (FCA).

39 FCT v Phillips, above n 38; and Australian Tax Office Tax Ruling TR 2006/2 (2006).

40 After issuing guidelines on Everett assignments in 2015, the ATO has now suspended them and continues to express concern about abusive arrangements: see for example ATO "Everett Assignments" (21 January 2019) <www.ato.gov.au>.

41 Hart v FCT [2004] HCA 26, respectively, Gummow and Hayne JJ at para [37]; and Callinan J at para [92].

42 The Australian Taxation Office has released detailed Guidelines on how it will apply the GAAR in such an integrated manner: Practice Statement PS LA 2005/24 (13 December 2005). 
Returning to the first aspect of a holistic approach to the GAAR, in Spotless Services, the High Court plurality said that "Part IVA is as much a part of the statute under which liability to income tax is assessed as any other provision thereof." 43 Yet the GAAR is a special kind of legislative tax rule that operates to ensure effectiveness of other statutory rules in the ITAA36 or ITAA97. Working out how the GAAR interacts with the structural rules of income tax is, as suggested by Craig Elliffe and John Prebble, a matter of statutory interpretation. ${ }^{44}$ However, unlike some other GAARs (perhaps including that of New Zealand), application of the Australian GAAR does not specifically require an investigation into the purpose of the general income tax provisions that it is said to defend. Rather, it requires an application of the statutory terms of the GAAR itself, in the holistic and interconnected manner noted above. This approach was made explicit in the joint judgment of Gummow and Hayne $\mathrm{JJ}$ in FCT $v$ Hart, ${ }^{45}$ when they reaffirmed that "Part IVA is to be construed and applied according to its terms ... Always the question must be whether the terms of the Act apply to the facts and circumstances of the particular case." 46

Through its application, Australia's GAAR, like other GAARs, operate in the evocative terms of Hikaka and Prebble to "open" the tax statute, otherwise a "closed" or autonomous system of rules, to the economic system or reality of economic transactions. ${ }^{47}$ However, the strict statutory approach for applying the GAAR seems to detach it from the underlying purpose of the relevant income tax provisions. Courts in applying the GAAR must be "paradox managers" who manage the relationship between the GAAR and the tax statute, as well as the dislocation of the tax statute from economic reality. ${ }^{48}$ The Federal Court of Australia, which decides most taxation law (and GAAR) cases, was established during the 1970s, in the context of the high public and policy concern about tax avoidance an led to the enactment of pt IVA. With this history, it may not be surprising that the Federal Court has acted as an important gatekeeper on tax avoidance, including defending the operation of the core provisions of the income tax statute from tax schemes in numerous cases. As Logan $\mathrm{J}$ observed, $\mathrm{pt}$ IVA is a "potent, effective riposte to such blatant, artificial and contrived schemes" as have been seen

43 FCT v Spotless Services Ltd (1996) 186 CLR 404 (HCA) at 414; consequently, the Court found that because s $177 \mathrm{D}(\mathrm{b})(\mathrm{ii})$ requires it, "regard is to be had to both form and substance", and the Duke of Westminster case has nothing pertinent to say.

44 Craig Elliffe and John Prebble "General Anti-Avoidance Rules and Double Tax Agreements: A New Zealand Perspective" (2009) 19 Revenue Law Journal 1.

45 FCT v Hart (2004) 55 ATR 712, [2004] HCA 26.

46 At [51]-[52], citing FCT v Spotless Services Ltd, above n 43.

47 Geraldine Hikaka and John Prebble "Autopoiesis and general anti-avoidance rules" (2010) 21 Critical Perspectives on Accounting 545 at 552-553.

48 At 553 . 
in the past. ${ }^{49}$ The Court has had a long engagement with pt IVA, as the government received advice on the drafting of the GAAR from Hill QC (prior to his appointment to the Federal Court), with Gleeson QC (as he then was, prior to appointment to the Supreme Court of New South Wales and then to the High Court) ${ }^{50}$ After his appointment to the Federal Court, Hill J sat on numerous pt IVA cases in which he sought to articulate a nuanced interpretive approach, which did not always align with the approach sought by the Commissioner. In contrast, the High Court has heard relatively few GAAR cases; this article refers to only a few in discussing the relationship of the GAAR with other provisions of the income tax statute.

\section{B Scheme}

The identification of a scheme sets the parameters for determining whether a taxpayer has obtained a tax benefit in connection with a scheme, and whether the dominant purpose of entering into, or carrying out the scheme, was to obtain the tax benefit. Part IVA can apply to a scheme carried out within or outside of Australia. ${ }^{51}$ Where a scheme is characterised narrowly by the Commissioner (for example, as a step or a limited number of steps in a broader transaction), some judicial analysis suggests that the scheme must be capable of standing on its own; ${ }^{52}$ nonetheless, it is accepted that a part of a scheme may be a scheme. ${ }^{53}$

FCT $v$ Peabody ${ }^{54}$ was the first case in which pt IVA received judicial examination by the High Court, and it established a broad interpretation of "scheme". Peabody concerned an arrangement to publicly float a business while generating tax-free capital gain, which was ultimately distributed to a beneficiary of a discretionary trust. The case revealed both the strengths and limitations of the GAAR. The Commissioner lost the case, as he could not establish the obtaining of a tax benefit by a beneficiary; however, his broad approach to "scheme" was upheld by the court.

Peabody illustrates the challenge of integrating the GAAR with complex statutory regimes in the income tax law, including the Capital Gains Tax (CGT) rules which were "bolted on" to the income

49 Justice John Logan "Mission accomplished? - a perspective on Part IVA of the Income Tax Assessment Act 1936" (Speech delivered at the 2012 Queensland Corporate Tax Retreat, Gold Coast, 6 September 2012) at 4.

50 Justice Ian V Gzell "The Legacy of Justice Graham Hill" (paper presented at Taxation Institute of Australia South Australian Division 2006 Annual Convention, 1 May 2006) at 5: "When both were at the Bar, Gleeson $\mathrm{CJ}$ and Hill $\mathrm{J}$ were retained to advise the government on a replacement for s 260 of the Income Tax Assessment Act 1936 (Cth). Part IVA was the ultimate result".

51 ITAA36, s 177D(5).

52 FCT v Hart, above n 45, at [9] per Gleeson CJ and McHugh J; but see Gummow and Hayne JJ at 724, [47].

53 FCT v Consolidated Press Holdings (2001) 207 CLR 235, as discussed in Hart, above n 52, per Gummow and Hayne JJ; and British American Tobacco Australia Services Ltd v FCT [2010] FCAFC 130 per Dowsett, Jessup and Gordon JJ at [32]-[38].

54 FCT v Peabody (1994) 181 CLR 359, [1994] HCA 43. 
tax statute in 1985, and the longer-standing trust taxation rules which give significant leeway to trustee discretion in identifying a taxable beneficiary. Today, the scheme in Peabody would likely be prevented by a TAAR: the value-shifting regime in Divs 723 to 727 of the ITAA97, which had effect from 1 July 2002 (it was not caught by the narrower terms of the pre-existing value-shifting rules in the statute). Divisons 723 to 727 are complex and rarely applied rules that are more likely to operate by deterring certain kinds of value-shifting transactions.

\section{Tax Benefit}

Identifying whether a taxpayer has obtained a "tax benefit" in connection with the identified scheme is a two-step enquiry. First, a taxpayer must have obtained a tax benefit from the scheme, which refers to many specific amounts of income, loss, credit, tax offset or withholding tax, for example: ${ }^{55}$

- $\quad$ "an amount not being included in assessable income of the taxpayer";

- $\quad$ "a deduction being allowable to the taxpayer";

- " "a capital loss being incurred by the taxpayer";

- "a foreign income tax offset being allowable to the taxpayer"; or

- "the taxpayer not being liable to pay withholding tax on an amount".

Secondly, it is necessary in each case to test whether the tax benefit would not have happened, or it is reasonable to expect that it would not have happened, if the scheme had not been entered into or carried out. ${ }^{56}$ This is tested on two alternate bases: ${ }^{57}$

(a) the annihilation approach: A comparison of the tax outcomes of the scheme identified against those of an alternate postulate that comprises only the events or circumstances that actually happened or existed (other than those that form part of the scheme); or

(b) the reconstruction approach: A comparison of the tax outcomes of the scheme against those of an alternate postulate involving a substitute set of arrangements that is a reasonable alternative to the scheme having regard to the scheme's substance; and any results or consequences that are or would be achieved by the scheme.

55 Set out in ITAA36, s 177C.

56 Australian Tax Office, above $\mathrm{n} 42$, at [78] to [82]: a guidance document released by the ATO and updated in September 2016 as it applies to schemes entered into, or commenced to be carried out, on or after 16 November 2012

57 ITAA36, ss 177CB(3)-(4). 
As discussed below, the "reconstruction" approach was inserted in reforms to the statute in 2013. The phrase "might reasonably be expected" has been held by the High Court to mean a reasonable expectation which is more than a possibility. This requires: ${ }^{58}$

a prediction as to events which would have taken place if the relevant scheme had not been entered into

or carried out and the prediction must be sufficiently reliable for it to be regarded as reasonable.

The "choice" principle reasserts itself in the limitation that a tax benefit is not caught by the GAAR if it arises as a result of an election, choice or other action taken by the taxpayer which is permissible under the tax legislation. ${ }^{59}$ However, where a scheme was entered into for the purpose of enabling such an action, the GAAR may still apply.

\section{Purpose}

For the GAAR to apply, the scheme must be entered into or carried out for the purpose of enabling a taxpayer to obtain a tax benefit. ${ }^{60}$ When applying the general GAAR, ${ }^{61}$ the relevant purpose is the sole or dominant purpose, ${ }^{62}$ that is, the "ruling, prevailing, or most influential purpose". ${ }^{63}$ The purpose is tested at the time the scheme was entered into and by reference to the law as it stood at that time. ${ }^{64}$ It is determined objectively, after considering the eight matters listed in $\mathrm{s} 177 \mathrm{D}(2)$, which are to be individually taken into account having regard to all the relevant evidence, and then weighed together, in arriving at the conclusion as to dominant purpose. ${ }^{65}$

The eight matters can be summarised as involving a consideration of how the scheme was implemented, the effects of the scheme, and the connection between the parties to scheme. ${ }^{66}$ Form or substance must be considered, as must the manner and form of the scheme and whether there is any economic effect of the scheme. Each of the matters must be considered by the Commissioner in making the decision whether to apply the GAAR, although not all of them have to point to a tax

58 FCT v Peabody, above n 54, at 385.

59 ITAA36, ss 177C(2)(a)(i), (2)(b)(i), (2)(c)(i) and 2(d)(i).

60 Section 177D.

61 Schemes falling within the definition in s 177A of the ITAA36, except those to which the MAAL and DPT provisions apply.

62 ITAA36, s 177A(5).

63 Spotless, above n 43, at 416.

64 CPH Property Pty Ltd v FCT (1998) 88 FCR 21 (FCA) at [42].

65 FCT v Hart, above n 52, at [92] per Callinan J.

66 Australian Taxation Office Law Companion Guideline LCG 2015/2 (2015). 
avoidance purpose. ${ }^{67}$ The factors must be balanced in determining whether the dominant purpose of entering into the scheme was the obtaining of the tax benefit.

The most famous, and contested, example of application of the GAAR concerned a very simple international transaction utilising a tax haven. In FCT $v$ Spotless Services Ltd,${ }^{68}$ the taxpayer invested AUD40 million in a bank account in the Cook Islands and took steps to enter into the bank account contract in that location so as to ensure the interest was sourced in the Cook Islands for tax purposes. This was done to take advantage of former s 23(q) of ITAA36 which provided an exemption for income derived by an Australian resident from a source outside Australia, as long as there was a liability for tax in the country where the income was derived (and it was evidenced that the tax was paid). As the Cook Islands levied a low withholding tax on interest paid offshore, it was accepted that this satisfied s 23(q).

The taxpayers in Spotless submitted that no tax benefit arose because without the scheme (had the Cook Islands deposit not been made) the relevant amount would not have existed. The High Court accepted the submissions of the Commissioner that the relevant counterfactual would have been investing the funds in an Australian bank account. The Court concluded that the taxpayers received a tax benefit in an amount equal to the interest less withholding tax which they received from the investment. More generally, the High Court stated in Spotless that a dominant purpose of obtaining a tax benefit could coexist with a commercial purpose, quoting an observation made by Harlan J of the United States Supreme Court: ${ }^{69}$

[T]he tax laws exist as an economic reality in the businessman's world, much like the existence of a competitor. Businessmen plan their affairs around both, and a tax dollar is just as real as one derived from any other source.

Various further aspects of the purpose requirement are discussed in this and other cases, including that an advisor's purpose can be ascribed to a taxpayer. ${ }^{70}$

This decision in Spotless is one way in which the GAAR is operationally "opened" to economic reality, while ensuring taxation of tax-motivated commercial transactions. Even this approach has its limits. The courts have tended to find for the taxpayer in cases involving widely used commercial and legal transactions, even though one reason why these transactions are widely used is that they may alter tax consequences. Examples include respecting the legal form and tax effect of sale-leaseback

$67 \quad F C T$ v Hart, above n 52.

68 Spotless, above $\mathrm{n} 43$.

69 Commissioner of Inland Revenue v Brown (1965) 380 US 563 at 579-580.

70 Commissioner of Taxation v Consolidated Press Holdings, above n 53. 
transactions in Eastern Nitrogen Ltd $v F C T^{71}$ and Metal Manufactures Ltd $v F C T ;{ }^{72}$ and permitting an immediate deduction for concession fees for access and use to build, own and operate a toll road in Citylink Melbourne Ltd $v$ Commissioner of Taxation. ${ }^{73}$

\section{E A Crisis for the GAAR?}

The requirement of establishing the sole or dominant purpose of obtaining a tax benefit in connection with a scheme, while apparently well settled, was tested afresh in an "unholy trinity"74 of cases in which the taxpayers argued that no action would have been taken were the scheme not entered into, so that pt IVA could not apply. ${ }^{75}$

In RCI Pty Ltd $v F C T,{ }^{76}$ the taxpayer was an Australian resident company which was a member of the James Hardie multinational group. The group undertook to move its corporate headquarters and centre of operations from Australia to the United States through a complex series of steps. RCI owned all the shares in the James Hardie Holding company (JHH), a United States company in the group. The transaction was, as in Peabody, a value-shifting arrangement but as it took place in March 1998, it was not subject to Divs 723 to 727 of the ITAA97. JHH revalued shares it held in another United States group company, resulting in a USD318 million increase in their value. JHH subsequently declared a dividend equal to this large amount out of its asset revaluation reserve. This dividend was exempt under Australia's participation exemption for dividends in s 23AJ of the ITAA36. Payment of the dividend was satisfied by the transfer of USD20 million (less US withholding tax) to RCI and a crediting of RCI's inter-company account with another group company, producing a "step up" in basis of the shares of RCI in $\mathrm{JHH}$, with the consequence of substantially reduced the taxable capital gain on disposal of those shares. In October 1998, RCI disposed of its shares in JHH ultimately including a capital gain of about USD46 million in its assessable income.

The Commissioner contended that the taxpayer had entered into a scheme to reduce the market value of its shares in JHH prior to their disposal. Further, if the taxpayer had not entered into the tax scheme, it was reasonable to expect that the taxpayer would nonetheless have proceeded with the reorganisation of the group involving a taxable disposal of the shares; consequently, RCI had obtained

71 Eastern Nitrogen Ltd v FCT (2001) 108 FCR 27, [2001] FCA 366

72 Manufactures Ltd v FCT (1999) 43 ATR 375, [1999] FCA 1712 (special leave refused).

73 Citylink Melbourne Ltd v Commissioner of Taxation (2004) 141 FCR 69, [2004] FCAFC 272, affirmed in FCT v Citylink Melbourne Ltd (2006) 228 CLR 1, [2006] HCA 35.

74 Kristen Deards QC in Kevin Lindgren (ed) Marking 40 years of Part IVA of the Income Tax Assessment Act 1936 (Australian Academy of Law, 2022) (forthcoming).

75 FCT v AXA Asia Pacific Holdings Ltd (2010) 189 FCR 205, [2010] FCAFC 134; RCI Pty Ltd v FCT [2011] FCAFC 104; and FCT v Futuris Corporation Limited [2012] FCAFC 32.

76 RCI Pty Ltd v FCT [2011], above n 75. 
a "tax benefit" in connection with the scheme. The Commissioner therefore issued an amended assessment including an additional USD478 million in RCI's assessable income. Rejecting the argument of the Commissioner, the Full Court of the Federal Court held that there was no possibility, let alone a reasonable expectation, that the taxpayer would have proceeded with the share disposal if the scheme had not been entered into. The reasonable expectation was, rather, that the taxpayer would not have disposed of its shares in JHH if the tax benefit were not obtained. The Court concluded that pt IVA did not apply to the scheme. The High Court denied special leave to appeal.

A similar result, producing a reduction in CGT, was achieved in FCT v Futuris Corporation Ltd, ${ }^{77}$ heard shortly after RCI. The Futuris scheme involved an internal restructure to transfer one division of a corporate group to another entity prior to its subsequent float. The internal restructure attracted the prior value shifting rules (former Div 19A of ITAA36), which caused a step up in the cost base of the shares leading to a significantly reduced net capital gain reported of AUD9.7 million. As in RCI, the Commissioner determined that pt IVA applied and identified an increase in the capital gain leading to an amended assessment for a total net capital gain of approximately AUD95.7 million. At first instance, Besanko J accepted the Commissioner's argument that as a matter of reasonable expectation, the taxpayer would have carried out the sale based on this counter-factual course of events. On appeal, the Full Court of the Federal Court held consistently with $R C I$ that no tax benefit arose because it was not reasonable to conclude that the taxpayer would have carried out the float in the way postulated by the Commissioner if it was going to result in reporting of such a significant capital gain.

The legislature responded by amending the GAAR so that null hypothesis, or "do nothing" alternate postulate, no matter how reasonable, could not be relied upon by the taxpayer. ${ }^{78}$ The new provisions have not yet been tested in the courts but ATO guidance asserts that: ${ }^{79}$

New section 177CB so significantly alters the conceptual framework of the tax benefit test that cases such as Federal Commissioner of Taxation v. RCI Pty Ltd (2011) 2011 ATC 20-075; (2011) 84 ATR 785; [2011] FCAFC 105 and Federal Commissioner of Taxation v. Futuris Corporation Ltd (2012) 205 FCR 274; 2012 ATC 20-306; [2012] FCAFC 32, can no longer be wholly regarded as representing the law, so far as the tax benefit concept is concerned, and should be treated with extreme caution. That this was Parliament's intention in enacting the amendments is clear from the legislative history and the extrinsic materials.

The 2013 amendments were intended to strengthen the integrated and holistic application of pt IVA by considering a taxpayer's dominant purpose as the "fulcrum" or "pivot" around which it

77 FCT v Futuris Corporation Ltd, above n 75.

78 Tax Laws Amendment (Countering Tax Avoidance and Multinational Profit Shifting) Act 2013 (Cth), sch 1. The amendments apply in relation to schemes that were entered into, or were commenced to be carried out, on or after 16 November 2012

79 Australian Tax Office, above n 42, at [85]. 
operates. ${ }^{80}$ It is noteworthy that evidence of the taxpayer's subjective intention regarding what the taxpayer would have done but for the scheme has been held to be relevant although not determinative in determining the alternate postulate, potentially muddying the "objectivity" of purpose which has been a hallmark of the GAAR. ${ }^{81}$ Where a taxpayer is able to identify other schemes which were genuinely considered prior to entering into or carrying out the scheme, this will weigh in the taxpayer's favour. ${ }^{82}$ A lack of evidence indicating genuine consideration of alternative arrangements may tell against the taxpayer. ${ }^{83}$

\section{F The GAAR and Complex Statutory Regimes in the Income Tax}

Many GAAR cases relate to simple transactions covered by the core provisions of the income tax law: the deductibility of an expense under s 8-1 of the ITAA97, as in many mass-marketed tax schemes; or the exemption of an item of income, as in Spotless. However, as evidenced by Peabody, $R C I$ and Futuris, it is more difficult to apply the GAAR where more complex legislative regimes are at stake. This difficulty may arise because these complex legislative regimes require significant abstraction of the taxation treatment from the real legal or economic facts of a transaction; it may be more difficult in this situation to close the gap between the law and economic reality. The most difficult challenge has arisen in the intersection of the regime for consolidated corporate groups in pt 3-90 of ITAA97 with pt IVA. ${ }^{84}$ Part 3-90 treats subsidiary companies as being subsumed for tax purposes under the "single entity" of the head company of the group. This tax fiction, layered on top of the legal fiction of separate entity status of companies in a group, creates numerous difficulties, especially in relation to mergers or spinoffs where companies join or leave the consolidated group.

In Macquarie Bank Ltd v FCT (Macquarie Bank), ${ }^{85}$ Edmonds $\mathrm{J}$ had to consider how the GAAR might attribute a tax benefit to a subsidiary company which, by operation of the statutory fiction arising on consolidation, had been subsumed into the "single entity" of the consolidated group. Edmonds $\mathrm{J}$ concluded that it was not possible to apply pt IVA to the subsidiary entity. On appeal, Middleton and Robertson JJ sought to achieve "the harmonious interaction of pts 3-90 and IVA" so as to give effect both to the GAAR and to the "legal fiction" of the single entity rule while not

80 Tax Laws Amendment (Countering Tax Avoidance and Multinational Profit Shifting) Bill 2013, explanatory memorandum, 1.71, discussing s 177D of the ITAA36.

81 FCT v Trail Bros Steel \& Plastics Pty Ltd (2010) 186 FCR 410 [Trail Bros].

82 At [36]; FCT v AXA Asia Pacific Holdings (2010) 189 FCR 204, [2010] FCAFC 134 at [139]; and FCT v Mochkin (2003) 127 FCR 185, [2003] FCAFC 15 at 209-210.

83 FCT $v$ Hart, above n 52, at [66] per Gummow and Hayne JJ.

84 Macquarie Bank Ltd v Commissioner of Taxation (2011) 85 ATR 409, [2011] FCA 1076 [Macquarie Bank].

85 Macquarie Bank Ltd v FCT, above n 84. 
'impermissibly "rewriting" legislation but rather properly construing it'. ${ }^{86}$ Unfortunately, the decision left the tax law in limbo with possibly no entity able to be assessed under pt IVA. Leave to appeal was refused, as there was in any event found to be no purpose of obtaining a tax benefit. ${ }^{87}$

In the subsequent case of Channel Pastoral Holdings Pty Ltd v FCT (Channel Pastoral), ${ }^{88}$ the Federal Court empanelled an unusual five member bench which affirmed that pt IVA can apply to the formation of a consolidated group by issuing an assessment to the subsidiary member of the group. Again, certainty has proved elusive. The result was reached by majority of 3:2; two leading tax judges on the Court, Pagone J (now retired) and Davies J, dissented, each expressing overlapping but not identical views of the law. Channel Pastoral has resolved some of the difficulties of interaction of the two regimes, but it has raised further complexities concerning how to assess to tax a legal entity that does not have a recognised taxable status. ${ }^{89}$

\section{G The GAAR is Part of the Statute but Deserves a Special Process}

Another indication of the unique nature of the GAAR as a statutory rule is the special administrative processes that have grown up since its enactment in 1981. Acknowledging the seriousness of applying the GAAR, and under external pressure from advisors and taxpayers, the Commissioner established the GAAR Panel to advise on its application. The Panel comprises external business and professional people and senior tax officers. The Chair of the Panel is a senior tax officer. The Panel has no statutory basis and is purely consultative, however, the role and its recommendations are taken seriously by the ATO. A decision to apply the GAAR must be referred to the Panel in most cases, unless clearance is received from the Chair or another senior officer. The primary purpose of the Panel, according to ATO guidelines, is to ensure objective and consistent decision-making across the ATO in application of the GAAR.

A taxpayer and/or their legal representative will usually be invited to make a written submission and to attend a GAAR Panel meeting and address the Panel; however, the guidance is clear that this is not a review process. A taxpayer invited to attend a Panel meeting should be given reasonable notice and information about the contentions of fact and the substance of the ATO approach in applying the GAAR, usually in a position paper, but is excluded from attending the Panel meeting when the ATO addresses the Panel. The taxpayer must be given an adequate opportunity to respond to the Commissioner's submissions regarding the application of the GAAR.

86 FCT v Macquarie Bank Ltd (2013) 210 FCR 164, [2013] FCAFC 13 at [135], [145] and [169] per Middleton and Robertson JJ.

87 FCT v Macquarie Bank Ltd [2013] HCATrans 185.

88 Channel Pastoral Holdings Pty Ltd v Commissioner of Taxation (2015) 232 FCR 162, [2015] FCAFC 57.

89 See further Narelle McBride and others "Part IVA and Consolidations: Channel Pastoral" (15 May 2015) Greenwoods Tax Brief <www.greenwoods.com.au>. 


\section{H TAARs and the GAAR}

While the GAAR in pt IVA should be considered an integrated whole, from the beginning, pt IVA has also included at least one TAAR. The targeted rule against dividend stripping in s 177E of the ITAA 1936 was enacted in pt IVA in 1981. That this rule was legislated in the same location as the GAAR and not elsewhere in the statute with the other rules for dividends can be explained by history and the particular salience of dividend stripping as a technique for tax avoidance in Australia. ${ }^{90}$

For dividend stripping to amount to "tax avoidance", s 177E requires a sole or dominant purpose of obtaining the tax benefit, similar to the GAAR. ${ }^{91}$ Apart from this similarity, s 177E is a "self contained code" with "specially tailored provisions" requiring a scheme of or in the nature of dividend stripping. It has other differences from the GAAR including the process of forming an "opinion" and a "deeming" both of a scheme and a tax benefit where the specific dividend stripping provisions are triggered. Interestingly, the dividend stripping rule in s 177E anticipated the "do nothing" counterfactual problem that arose in RCI and led to the amendments to the GAAR of 2013. A dividend strip required several stages of transaction and a plausible alternative is that the taxpayer simply retains the profits in the company. This issue was identified in the Explanatory Memorandum that introduced the rule. ${ }^{92}$ The location of the dividend stripping rule in pt IVA has led to some confusion about the interaction of s 177E and s 177D - that is, the suggestion that the general GAAR on its own terms may still apply even if s $177 \mathrm{E}$ does not. ${ }^{93}$

After the introduction of dividend imputation in 1987, a new set of anti-trading and streaming rules were required for franking credits which quickly became a valuable tax commodity which taxpayers sought to trade, but which was constrained with many conditions and an expectation of some "wastage" of franking credits. The anti-trading and streaming rules for franking credits gradually expanded over time and in 1999 a franking credit anti-avoidance rule was enacted in s 177EA of pt IVA. Section 177EA requires a scheme and a purpose of obtaining a franking benefit, but the purpose threshold is significantly lower than the "sole or dominant purpose" of the GAAR, as it requires only a "not incidental" purpose. ${ }^{94}$ The eight factors to be considered for objective purpose for the GAAR are to be taken into account but they are not the only or exclusive factors, as everything else "relevant"

90 As evidenced in numerous cases including Patrick Corporation Ltd v FCT (1974) 3 ALR 251 (HCA); and Investment \& Merchant Finance Corp Ltd v FCT (1970) 120 CLR 177 (HCA).

91 Commissioner of Taxation v Consolidated Press Holdings Ltd, above n 53.

92 For a detailed discussion of this and other issues see Pagone, above n 21, at 94ff.

93 CPH Property Pty Ltd v FCT, above n 64; and see Pagone, above n 21, at 107.

94 ITAA36, s 177EA(3)(e). 
should also be considered. Again, as Pagone has suggested, this raises "interesting, if perhaps avoidably abstruse, questions of interpretation" about the interaction of s 177EA with the GAAR. ${ }^{95}$

\section{THE GAAR AND INTERNATIONAL TAX}

\section{A Anti-Avoidance and International Jurisdiction}

The Australian GAAR seems in some circumstances to play a structural role in ascertaining the boundaries of Australian source tax jurisdiction. This seems to be the case in the application of the general rule to international transactions and in the MAAL and DPT. Australia's strong approach to protecting its source jurisdiction is because of its history (continuing today) as a capital-importing country with a large resource export sector. Australia has always applied source taxation that is broad relative to OECD norms, evidenced in Australia's broad definition of "permanent establishment" in s 6 of the ITAA36 and tax treaties; broad definition of "source"; higher withholding tax rates; and broad definitions of outbound interest and royalties paid to non-residents. ${ }^{96}$ The approach is reflected in Australia's reservations to the OECD Model Convention, although over time Australia's tax treaty practice has moved towards the OECD approach. ${ }^{97}$

The application of anti-avoidance rules in the international arena has been the subject of much debate. ${ }^{98}$ Historically, where tax benefits were obtained under the terms of bilateral tax treaties, it was a widely held view that a domestic GAAR could not apply to such treaty abuse. ${ }^{99}$ In contrast, today it is accepted that the application of domestic GAARs, whether statutory or judicial, especially relating to substance over form, will be generally consistent with tax treaties. ${ }^{100}$ The OECD-G20 BEPS project Action 6 report accepted that domestic GAARs or judicial approaches, such as economic substance, sham, business purpose, step-transaction, abuse of law or fraus legis, would not generate a conflict with a tax treaty "in the vast majority of cases". ${ }^{101}$

95 Pagone, above n 21, at 120.

96 Board of Taxation International Taxation: A Report to the Treasurer (2003) at 89.

97 OECD Model Tax Convention on Income and on Capital (2019): see for example C(5)-70, C(5)-71, C(10)29, C(10)-30, C(11)-21, C(12)-24 and C(12)-25. See further Piotr Klank and Miranda Stewart "Australia Global Tax Treaty Commentaries - Country Policy and Practice" (IBFD Global Tax Treaty Commentaries, 2021)

98 David Duff "Tax Avoidance in the $21^{\text {st }}$ Century" in Chris Evans and Richard Krever (eds) Australian Business Tax Reform in Retrospect and Prospect (Thomson Reuters, 2009) 477 at 483.

99 Stef van Weeghel "General Report" in Tax treaties and tax avoidance: application of anti-avoidance provisions (online ed, vol 95a, International Fiscal Association (IFA), Cahiers de droit international, 2010) at 2.4.1 and. 2.5.

100 At 2.4.1.

101 OECD-G20 Action 62015 Final Report: Preventing the Granting of Treaty Benefits in Inappropriate Circumstances (OECD Publishing, Paris, 2015) at 89; and OECD Model Tax Convention on Income and on 
Australia's position on the GAAR, tax treaties and international transactions has been less ambivalent. Just as it has preserved a stronger source tax base, Australia has preserved the application of the GAAR in all its tax treaties. The International Tax Agreements Act 1953 (Cth) provides that tax treaties and other international agreements have the force of law in Australia. By s 4(1) of that Act, the ITAA97 and ITAA36 are "incorporated and shall be read as one" with it; and by s 4(2), the provisions of the International Tax Agreements Act including terms of tax treaties "have effect notwithstanding anything inconsistent with those provisions contained in the Assessment Act (other than Part IVA of the Income Tax Assessment Act 1936)". ${ }^{102}$ There has been a debate about whether this is also the case in New Zealand. ${ }^{103}$

\section{$B$ The Operation of the GAAR on International Transactions}

We can observe the extension of the GAAR into matters of international tax jurisdiction much earlier than the enactment of the MAAL and DPT, in the case of Spotless, discussed above. Spotless has been described as a "florid example" of a business transaction that was found to be tax avoidance subject to the GAAR. ${ }^{104}$ Yet despite some flourishes in implementation, including an international bank guarantee, the transaction was straightforward: A genuine bank deposit in the Cook Islands, deriving genuine interest. Even the finding that the source of the interest was the Cook Islands, although somewhat formalistic, followed logically from the existence of a genuine bank account in that foreign jurisdiction. There was no suggestion, for example, that it was a conduit arrangement and the transaction complied with all the legal requirements of then-applicable s 23(q) of the ITAA36.

In Spotless the High Court provides the clearest authority that a tax purpose may coexist with a commercial purpose and once this is accepted, applying the terms of the GAAR to the transaction in Spotless seems relatively straightforward. Yet, one may query whether it is over-broad. One may fairly ask, why else would an Australian resident taxpayer with access to Australian banking services put money in a Cook Islands bank account? In effect, Spotless altered the jurisdictional boundary of the Australian income tax law by extending taxation to interest derived in the Cook Islands, despite the terms of the legislative exemption being fully satisfied.

Capital: Condensed Version 2017 - Commentary on Article 1 (18 December 2017 at [2], [12] and [13]. This is consistent with the approach in paragraph 22(1) of OECD Model Tax Convention on Income and on Capital: Commentary on Article 1 (28 January 2003), Models IBFD.

102 Satyam Computer Services Ltd v Commissioner of Taxation [2018] FCAFC 172 at [16].

103 Craig Elliffe and John Prebble "General Anti-Avoidance Rules and Double Tax Agreements: A New Zealand Perspective" (2009) 19 Revenue Law Journal 1, presents two perspectives on the issue, regarding whether section BG 1 of the Income Tax Act overrides New Zealand's tax treaties, which requires the interpretation of section $\mathrm{BH} 1(4)(\mathrm{a})$.

104 Tony Slater "Commentary: Tax Avoidance in the $21^{\text {st }}$ Century" in Chris Evans and Richard Krever (eds) Australian Business Tax Reform in Retrospect and Prospect (Thomson Reuters, Australia, 2009) 505 at $503-$ 513 . 
The real problem lay with Australia's outdated exemption rule, which had already been identified as such but had not yet been replaced. The case would never have come to court - the offshore bank account would not have been attractive - even a year later. This was because from 1 July 1987, the Parliament replaced the exemption with a foreign tax credit, a far more suitable solution. ${ }^{105}$ This reform was a tardy response by the Parliament to a recommendation of the Asprey Committee made a decade earlier. ${ }^{106}$ Subsequently, controlled foreign company rules were introduced in pt $\mathrm{X}$ of ITAA36 to affirm that worldwide tax jurisdiction. It was nearly another decade before the appeal in Spotless reached the High Court, by which time the s 23(q) exemption was long gone.

The abolition of the foreign income exemption removed the last vestige of Australia's historic source-based territorial income tax system. Reforms of the 1980s and 1990s sought to expand international tax jurisdiction, moving Australia towards a "worldwide" income tax system Australia did not take steps to reform its transfer pricing rule (formerly s 136 of ITAA36 and now in Div 815 of ITAA97) until much later, despite this also being recommended by the Asprey Committee. These international tax reforms solved the Spotless problem, but brought their own complexities: In 1996, the GAAR was extended to apply to schemes to obtain a foreign tax credit (s 177C(1)(bb)). The 1990s were an era of very substantial foreign tax credit planning in the United States, leading to the application of judicial anti-avoidance approaches there, as well as some legislative reform. As Australia's major trading partner, it is likely that some of the United States FTC schemes and planning filtered through to Australia.

In the next decade, following the Board of Taxation's Review of International Tax Arrangements in 2002, the current participation exemption system for active business income of corporations was enacted. ${ }^{107}$ The taxpayer in Spotless would not have been eligible for the exemption in respect of interest earned on a bank account.

In other cases involving international transactions and tax havens, the GAAR has not been applied to such effect for the Commissioner. One case about "base eroding" deductible payments offshore to a captive insurance company located in Singapore reached the opposite conclusion. WD \& HOWills (Australia) Pty Ltd v FCT (Wills) ${ }^{108}$ was decided before the Spotless Services appeal was finalised in the High Court. In Wills, Sackville J of the Federal Court concluded that a deduction was allowed by the taxpayer in Australia for its premiums paid to the captive insurance company in Singapore because this was a genuine payment at a reasonable commercial price even though to a related party, and had

105 Section 23(q) was repealed by Act No 51 of 1986. A foreign tax credit had applied to dividends previously under s 45 of the ITAA36. Now the Foreign Income Tax Offset rules in Div 770 of ITAA97.

106 Taxation Review Committee Asprey Report: Full Report (AGPS, 1975).

107 Australian Treasury, Board of Taxation Review of international Tax Arrangement (RITA) (Consultation Paper, 2002).

108 WD \& HO Wills (Australia) Pty Ltd v FCT (1996) 65 FCR 298, (1996) 32 ATR 168 (FCA). 
commercial benefits of obtaining the insurance and claims management services. The "captive" insurance company was found to be sufficiently commercial although the company itself did nothing but contract with another entity. Having found sufficient commercial purpose, Sackville J concluded there was not a sole or dominant purpose of obtaining a tax benefit in respect of a scheme. It is interesting to consider whether a different result would have followed had this case been heard after the High Court decision in Spotless Services was handed down, accepting the coexistence of tax and commercial purposes. The case raises similar questions as Spotless in the use of a legal entity in a tax haven; however, the features that the entity was a related party and did not have any substantial activities might be indicators of tax avoidance.

In contrast, in Consolidated Press Holdings v FCT, ${ }^{109}$ the GAAR was applied, not to assert taxing jurisdiction but to protect the operation of the legislative rules that defined and limited that jurisdiction. The High Court concluded that the interposing of an Australian resident corporation in an international reorganisation, so as to bypass the limitation on deductibility of interest expense in relation to foreign income, attracted pt IVA, although in other respects, the transaction was found not to attract the GAAR. The interposition of the entity was intended to circumvent a limit on deductions in generating foreign income. This decision evinces an appropriate role for a GAAR, to fill gaps and ensure that the existing statutory framework operates as intended, rather than drawing the fundamental jurisdictional boundaries which should be provided by Parliament.

This brief summary illustrates the interconnected nature of anti-abuse, and structural rules for international tax jurisdiction, which is the historical context for the most recent BEPS developments. One more challenging aspect of BEPS is international tax arbitrage. Tax treaties have traditionally been aimed at eliminating double taxation (in two jurisdictions) and until recently, the general view was that tax treaties did not have a purpose of preventing double non-taxation. ${ }^{110}$ Where transactions produce advantageous tax outcomes as a result of the interaction of two or more tax systems, it has been assumed (and was the practical reality), until very recently, that this "international tax arbitrage" was not able to be targeted by a unilateral GAAR because it was not a product of any one tax system. ${ }^{111}$ Wardzynski suggested, "if double non-taxation was intended to be banned, there would be no distinction between abusive and non-abusive treaty shopping, and the GAAR would be supplemented with a subject-to-tax provision". ${ }^{112}$

109 Consolidated Press Holdings v FCT [2001] HCA 32.

110 M Lang General Report in Double non-taxation (Online ed, vol 89a, IFA, Cahiers de droit international, 2004) at 2.2.6.

111 See for example David H Rosenbloom "International Tax Abritrage and the 'International Tax System'" (2000) 53 Tax Law Review 137.

112 A Wardzynski The Limitation on Benefits Article in the OECD Model: Closing Abusive (Undesired) Conduit Gateways (2014) 68 Bull Intl Taxn 9 at 2.3. 
An example in Australia is Mills v FCT, ${ }^{113}$ in which the Commonwealth Bank of Australia benefited from reduced tax on a cross-border hybrid capital-raising security, at the expense of both the New Zealand revenue (mostly) and the Australian revenue. The bank issued its PERLS V security which stapled a preference share, issued by the Australian branch, with a note issued by the New Zealand branch that would carry interest. Under Australia's debt-equity rules in Div 974 of ITAA97, the PERLS V stapled security was treated as equity; although the return on the security was called "interest", distributions were treated like an ordinary dividend and carried a franking credit. The security also qualified as tier-1 capital for Australian capital regulatory purposes. Under New Zealand income tax law, the note was treated as debt (analysed on its own, separately from the preference share). This provided a deduction for the distribution characterised as interest for New Zealand tax purposes.

In Mills v FCT (2011), ${ }^{114}$ the Full Court of the Federal Court found for the Commissioner, applying s 177EA, the franking credit anti-avoidance rule. Jessup J, with whom Dowsett J agreed, concluded that the Bank had a "non-incidental purpose" of enabling its investors in the PERLS V securities to get the franking credits which were central to the scheme. The fact the bank received a deduction in New Zealand was relevant. So, the anti-avoidance rule applied - to deny the investors the benefit of the franking credits. Edmonds J dissented, in part on the basis that the New Zealand tax outcome was not relevant. On appeal, the High Court found for the bank. Gageler J, in the High Court, accepted that the deduction in New Zealand was relevant in applying the Australian anti-abuse rule, but concluded that even though the franking credits were crucial for investors, the main purpose of the transaction was capital-raising and not the tax advantage.

\section{$C$ The MAAL and DPT}

The OECD-G20 BEPS project that commenced in 2013 responded to public concern about "abuse" or "avoidance" of tax by large MNEs. The concern is revealed in parliamentary inquiries into aggressive tax planning. ${ }^{115}$ The BEPS recommendations in response tend to emphasise anti-abuse or economic substance approaches. ${ }^{116}$ Recommended measures range from complex TAARs, such as the hybrid mismatch rules that were enacted in Div 832 of the ITAA97 (BEPS Action 2), to general

113 Mills v FCT [2012] HCA 51.

114 Mills $v$ Commissioner of Taxation [2011] FCAFC 158

115 Senate Economic References Committee, Parliament of Australia "An inquiry into tax avoidance and aggressive minimization by corporations registered in Australia and multinational corporations operating in Australia" <www.aph.gov.au>.

116 Miranda Stewart "Abuse and Economic Substance in BEPS" (2015) Bulletin for International Taxation (June/July) 399-409. 
statements as in the adoption of the new Commentary on art 1 of the OECD Model ${ }^{117}$ and the introduction of a treaty abuse rule, the Principal Purpose Test (PPT) (BEPS Action 6). In contrast, the 2021 Inclusive Framework Consensus on Pillar One and Pillar Two focuses on the extension and reformulation of tax jurisdictional rules through the establishment of thresholds, new taxing rights and minimum tax rules that do not depend on a finding of tax avoidance. ${ }^{118}$

Soon after the OECD-G20 BEPS project commenced, Australia "jumped the gun" and took unilateral measures to ensure it could tax MNEs which appeared to be "avoiding" the establishment of a taxable permanent establishment in Australia, while marketing goods and digital services to Australian consumers - the Multinational Anti-Avoidance Law (MAAL), informally known as the "Google tax". ${ }^{119}$ The MAAL in pt IVA aimed to stop large MNEs doing international tax planning that may "erode" Australia's corporate tax base. ${ }^{120}$ The MAAL owes its origins to developments a year earlier in the United Kingdom at a time when large MNEs were attracting considerable attention for low tax paid in the United Kingdom. ${ }^{121}$ During this time, the GAAR became an element in a broader political discourse about a "fair share" of tax from multinational enterprises.

In December 2014, Chancellor George Osborne signalled his intention to introduce a so-called diverted profits tax. ${ }^{122}$ Draft legislation was published that month, well ahead of the BEPS Final Reports and consensus-based reforms. ${ }^{123}$ The two limbs of the United Kingdom diverted profits tax, which is still operational, aim to ensure that MNEs cannot artificially avoid a permanent establishment in the United Kingdom and to impose a special tax on profits considered to be artificially diverted, at a rate of 25 per cent, higher than the (then) headline corporate tax rate of 21 per cent. ${ }^{124}$

117 Most recently, OECD Model Tax Convention on Income and on Capital: Commentary on Article 1 (15 July 2014), Models IBFD.

118 Inclusive Framework on BEPS Statement on a Two-Pillar Solution to Address the Tax Challenges Arising from the Digitalisation of the Economy (8 October 2021). Available at <www.oecd.org>.

119 GS Cooper "Implementing BEPS, or Maybe Not - the Australian Experience One Year On" [2017] NZLR 145 at 167.

120 Commissioner of Taxation ATO Annual Report (2017) at 30; and Australian Taxation Office ATO clarifies impact of the MAAL (25 October 2017) <www.ato.gov.au>.

121 See for example J Mather, J Hutchinson and N Khadem "Backlash over Apple's low taxes" (7 March 2014) Australian Financial Review 1 at 7; and J Dagge "Google pays 16pc tax rate" Herald Sun (Melbourne, Australia, 2 May 2015) at 53.

122 G Osborne "Chancellor George Osborne's Autumn Statement 2014 Speech" Oral Statement to Parliament (3 December 2014) Gov.UK <www.gov.uk>.

123 See Tim Legrand (ed) "Structure, Agency and Policy Learning: Australia's Multinational Corporations Dilemma" in Learning in Public Policy at 215-241.

124 HM Revenue and Customs (UK) "Guidance Rates and allowances: Corporation Tax" (Updated 10 June 2019) <www.gov.uk>; See HM Revenue and Customs Diverted Profits Tax <https://assets.publishing. 
After the G20 meeting in 2015, Treasurer Hockey announced a joint working group which would seek to build on the United Kingdom's experience introducing the DPT. ${ }^{125}$ The Treasurer officially announced the MAAL in the 2015 May budget ${ }^{126}$ and it was quickly enacted. ${ }^{127}$ Treasurer Joe Hockey indicated that Australia was leading international developments: ${ }^{128}$ "Australia and the UK will work together to drive the global agenda, going after multinationals that are shifting profits away from the countries where they earn the income." Australia would then go even further: ${ }^{129}$ "Whilst we recognise the OECD is undertaking work which Australia initiated and promoted last year, we obviously want to go further and faster". This amendment was done by a Liberal-National party government, as was the original enactment of pt IVA. The government later claimed that the reform was consistent with the BEPS Action 7 recommendations. ${ }^{130}$

Importantly, by virtue of their location in pt IVA of ITAA36, the MAAL and DPT prevail by s 4(2) over any contrary treaty provision. This ensures their effective operation and obscures any potential "treaty override" effect of the MAAL and DPT, arising from the extension of taxing rights beyond the definition of PE, and attributable profits, in most tax treaties.

\section{$D$ Operation of the MAAL}

The MAAL aims to counter schemes entered into by MNEs to avoid the attribution of business profits to a permanent establishment in Australia. ${ }^{131}$ A "significant global entity" (SGE) is, broadly, an entity (or member of a group of consolidated entities) with annual global income of AUD1 billion or more. The MAAL applies if, under a scheme or in connection with a scheme:

- $\quad$ a foreign entity makes a supply of any good or service ${ }^{132}$ to an Australian customer;

service.gov.uk>; the rate of the general UK DPT will increase from 25 per cent to 31 per cent from 1 April 2023: HM Revenue and Customs Policy Paper: Change to the Diverted Profits Tax rate from 1 April 2023 (3 March 2021)

$125 \mathrm{~J}$ Hockey "UK and Australia agree to collaborate on multinational tax" (press release, 19 April 2015); and M Gilleard "Australia and UK want to go 'further and faster' than the OECD on diverted profits actions" (27 April 2015).

126 Commonwealth of Australia Budget Measures 2015-16: Budget Paper No 2 (12 May 2015).

127 Combating Multinational Tax Avoidance Bill 2015 (Cth).

128 Interview with Joseph Hockey, Australian Treasurer (ABC Insiders, 19 April 2015) <www.abc.net.au>.

129 Interview with Joseph Hockey, above n 128.

130 Hon Scott Morrison "OECD report supports Australian Government action on multinational tax avoidance" (press release, 6 October 2015): available here <http://sjm.ministers.treasury.gov.au>.

131 ITAA36, s 177DA.

132 "Supply" is defined broadly to include any good or service, but does not include the supply of an equity or debt interest, or options; and does not apply to intra-group supplies: ITAA36, s 177A(1). 
- an Australian entity, ${ }^{133}$ that is an associate ${ }^{134}$ of or is commercially dependent ${ }^{135}$ on the foreign entity, undertakes activities directly in connection with the supply;

- some or all of the income derived by the foreign entity is not attributable to an Australian permanent establishment; and

- the principal purpose, or one of the principal purposes of the scheme, is to obtain an Australian tax benefit or to obtain both an Australian and foreign tax benefit.

The concept of "principal purpose, or one of the principal purposes" is clearly a different test from "sole or dominant purpose" in the general GAAR, and a "non-incidental purpose" in the franking credit anti-abuse rule.

Although it was originally suggested that the MAAL would target only about 30 MNEs, the SGE threshold was subsequently claimed to impact about 1,000 entities operating in Australia. ${ }^{136} \mathrm{~A}$ substantial time for transition to the new regime, which commenced on 1 July 2016, was provided with the clear expectation that MNEs potentially subject to the rule would restructure their affairs so as to establish themselves more clearly within Autralia's taxing jurisdiction. Commissioner Jordan emphasised that the: ${ }^{137}$

message is clear - if you do business in Australia, you must pay your fair share of tax on the profits you earn here; whether you are a domestic or multinational company, big or small.

The ATO in 2017 stated in Senate Estimates and on its website: ${ }^{138}$

The MAAL bolsters the capabilities of the ATO in combatting tax avoidance and was instrumental in the closure of almost a quarter of the $\$ 4$ billion in additional assessments last year. A number of companies, notably Google and Facebook, have stated publicly they will now return Australian sourced sales to Australia. This is as a result of the operation of the MAAL. We anticipate additional taxable sales now returned to Australia will amount to over $\$ 7$ billion each year. That's $\$ 7$ billion in sales booked and the appropriate profit of these activities taxed in Australia for the first time, and locked in for the future.

133 That is, legal entities (including trusts and partnerships) resident in Australia: ITAA36, s 336. Reference to an "Australian entity" in this section includes reference to an Australian permanent establishment of an entity: see ITAA36, s 6(1).

134 The meaning of "associate" varies depending on the type of foreign entity and on the type of entity with a presence in Australia: IYAA36, s 318.

135 This term is not defined in the legislation. See Australian Tax Office, above $\mathrm{n} 66$ for a list of the factors the ATO considers relevant to determining if an entity in Australia is commercially dependent on an SGE.

136 Deloitte "Multinational Tax Avoidance Measures" (2015) Tax Insights <www.deloitte.com>.

137 Chris Jordan "Building trust and confidence in our tax system" (Speech given at the Tax Institute's 31st National Convention, Melbourne, 3 March 2016).

138 Australian Tax Office "ATO clarifies impact of the MAAL" (press release, 25 October 2017). 
One consequence of restructuring following the MAAL is that payments offshore to related companies may now be subject to royalty withholding tax, if a broader approach to the definition of "royalty" is adopted as proposed in draft Tax Ruling TR 2021/D42.

Although Australia essentially utilised the MAAL to "extend" its source or permanent establishment jurisdiction, it did not adopt all recommendations that aim to prevent artificial avoidance of PE status under BEPS Action 7. ${ }^{139}$ Australia's tax treaties with Germany (2015) and Israel (2019) both have embraced the MLI updates, including art 12 on PE (which was reserved in Australia's instrument of ratification) but Australia retains a reservation to ensure that MNEs that carry out mining operations will have a taxable presence in Australia. ${ }^{140}$ Consistent with Australia's longstanding broad interpretation of PE, Australia adopted arts 13 and 14 of the MLI in full. However, Australia did not adopt art 10 on PEs in third countries, nor art 12 on the avoidance of PE status through commissionaire arrangements. The former reservation was made on the basis that such a rule is not included in any of Australia's DTAs and further analysis would be required in an Australian context. The latter reservation was a response to industry consultation. Industry considered that the MAAL adequately captured such arrangements without adding another layer of rules to safeguard Australia's revenue.

\section{E Operation of the DPT}

The DPT applies to MNEs seeking to avoid tax by diverting profits out of Australia. ${ }^{141}$ This further step was taken in the 2016 budget. ${ }^{142}$ The DPT rules impose a penalty tax at a rate of 40 per cent in some circumstances and increase penalties if significant information about cross-border operations was not supplied the ATO. In some respects, the Australian DPT mirrors the United Kingdom rule of the same name, but it also has significant differences. The DPT applies to SGEs where one of the persons who entered into the scheme is a foreign related party of the taxpayer. It aims to ensure that the tax paid by SGEs properly reflects the economic substance of their activities in Australia and to prevent the diversion of profits offshore through "contrived" arrangements involving related parties.

The DPT in s 177J applies if, under the scheme or in connection with the scheme: ${ }^{143}$

- a taxpayer ("the relevant taxpayer") has obtained a tax benefit in connection with the scheme in an income year;

139 OECD "Action 7: Permanent Establishment Status" <https://www.oecd.org>.

140 OECD Model Tax Convention on Income and on Capital: Condensed Version 2017 - Commentaries on Article 5 (18 December 2017) at 188.

141 Sections $177 \mathrm{H}-177 \mathrm{R}$.

142 Commonwealth of Australia Budget Measures 2016-17 - Budget Paper No 2 (3 May 2016).

143 ITAA36, s 177J(1). 
- a foreign entity, that is an associate of the relevant taxpayer, entered into or carried out the scheme or is otherwise connected with the scheme;

- the principal purpose, or one of the principal purposes of the scheme, is to obtain an Australian tax benefit or to obtain both an Australian and foreign tax benefit; and

- none of the following exceptions apply:

(i) the $\$ 25$ million income test; ${ }^{144}$

(ii) the sufficient foreign tax test; ${ }^{145}$ or

(iii) the sufficient economic substance test. ${ }^{146}$

The DPT provisions commenced on 1 July 2017 but have retrospective effect to schemes or arrangements prior to commencement. The rule essentially captures schemes that attribute inadequate profits to an Australian taxpayer. The consequences of triggering the DPT is the imposition of tax at a penalty rate of 40 per cent, limited review and restricted dispute processes, and no access to mandatory binding MAP arbitration. ${ }^{147}$ The Commissioner subsequently released a ruling and other guidance to assist with understanding when the latter two exceptions will apply. ${ }^{148}$

\section{F The Principal Purpose Test}

Australia has adopted one further anti-abuse measure arising out of the BEPS project. The Action 6 report recommended adoption of a Principal Purpose Test (PPT) or an expanded limitation of benefits rule to deny treaty benefits as a minimum standard in the Multilateral Instrument. ${ }^{149}$ The PPT has been adopted by Australia in most of its tax treaties. Australia has also adopted the recommendation that tax treaties include in the title and preamble that the treaty is for "the prevention of tax evasion and avoidance" and emphasises that treaties should not create: ${ }^{150}$

144 Section $177 \mathrm{~K}$.

145 Section $177 \mathrm{~L}$. Broadly speaking, this test will be satisfied if the amount of foreign income tax payable in respect of the scheme is 80 per cent or more of the amount of the tax benefit multiplied by the standard Australian corporate tax rate (currently 30 per cent for large businesses), in relation to the DPT tax benefit.

146 ITAA36, s 177M.

147 Sections $177 \mathrm{H}-177 \mathrm{R}$.

148 Australian Tax Office Law Companion Ruling 2018/6 Diverted Profits Tax (26 September 2018); Australian Tax Office Practice Statement Law Administration PSLA 2017/2 Diverted profits tax assessments (2017); and Australian Tax Office Practical Compliance Guideline PCG 2018/5 Diverted profits tax (26 September 2018).

149 See OECD "Action 6 Prevention of tax treaty abuse" (6 October 2015) <www.oecd.org>.

150 At 62 . 
opportunities for non-taxation or reduced taxation through tax evasion or avoidance (including through treaty-shopping arrangements aimed at obtaining reliefs provided in this Convention for the indirect benefit of residents of third States).

The PPT is expressed as follows: ${ }^{151}$

Notwithstanding the other provisions of this Convention, a benefit under this Convention shall not be granted in respect of an item of income or capital if it is reasonable to conclude, having regard to all relevant facts and circumstances, that obtaining that benefit was one of the principal purposes of any arrangement or transaction that resulted directly or indirectly in that benefit, unless it is established that granting that benefit in these circumstances would be in accordance with the object and purpose of the relevant provisions of this Convention.

The OECD Commentary on the PPT explains that it is intended to ensure that tax treaties apply:152

to provide benefits in respect of bona fide exchanges of goods and services, and movements of capital and persons as opposed to arrangements whose principal objective is to secure a more favourable tax treatment.

When determining whether the MAAL or DPT provisions apply to a scheme, regard is to be had to some additional matters (in addition to the eight factors set out above in making a GAAR determination). ${ }^{153}$ There is not much guidance on what would breach the PPT, although there is some guidance as to when a treaty benefit can be shown not to be a principal consideration. The tendency is to identify visible factors such as a commercial presence, or existence of an entity in a tax haven, while setting the purpose threshold rather low. ${ }^{154}$ The Action 6 Report observes that countries should modify existing domestic and international tax rules "in order to more closely align the allocation of income with the economic activity that generates that income". ${ }^{155}$ The Commentary states that: ${ }^{156}$

where an arrangement is inextricably linked to a core commercial activity, and its form has not been driven by considerations of obtaining a benefit, it is unlikely that its principal purpose will be considered to be to obtain that benefit.

151 At 65 (emphasis added).

152 At 68 .

153 ITAA36, ss 177DA(2), 177J(1)(b) and 177J(2).

154 OECD Preventing the Granting of Treaty Benefits in Inappropriate Circumstances (2014)

155 At 17.

156 At 70 (emphasis added). 
In Australia, the ATO has recently released guidance on "principal purpose" 157 but the application of the PPT has not yet been considered by the courts.

\section{THE GAAR AT 40: CRISIS OR RENEWAL?}

the fuzzy territory on the edge of honesty ... that grey land where 'almost right' fades into the rat-fleshcoloured zone of 'nearly wrong'.

Peter Carey The Tax Inspector (Vintage International, Queensland, 1993) at 170.

Despite the existence of a GAAR in Australia's income tax law for more than a century, and in its present incarnation in pt IVA for 40 years, we still struggle to define "tax avoidance". There remains the constant challenge of "uncertainty" or game of risk between taxpayers and the ATO. One view is that "tax avoidance" is, in essence, an empty term, taking its meaning only from the operation of the statutory GAAR itself. This was expressed by David Bloom QC, when he said that "tax avoidance is that which is struck down by the GAAR and the TAARs; and, axiomatically, it is always unsuccessful, always ineffective." 158 Another view, suggested by John Prebble, is that we can identify "tax avoidance" independently of the GAAR: ${ }^{159}$

The concept of tax avoidance is well-known ... we mean, broadly, the form of tax minimisation that involves the creation or deployment of commercial arrangements that specifically seek to use (or misuse,

or abuse) the law to minimise tax that would otherwise be payable.

This view identifies the purpose or intent of the statutory regime as the crucial element in identifying "use, misuse or abuse" of that law to minimise tax; however, elsewhere, John Prebble has observed the difficulty in, defining tax avoidance either "exhaustively" or "in terms of legal rules at all". 160

The Australian GAAR does not specifically require identification of the purpose of the income tax statutory provisions that it defends. Nonetheless, to understand if the GAAR is doing its job, or if Parliament should be called upon to amend the structural rules of the income tax law, we need to keep that purpose - for example, establishing the boundaries of international tax jurisdiction - firmly in mind. This enables us to make normative claims about the scope and operation of a GAAR, and to identify transactions and events that should be, or should not be, captured by the GAAR.

157 Australian Tax Office Practice Statement Law Administration PS LA 2020/2 (2020); see also Australian Tax Office, above n 66; and Australian Tax Office above n 148.

158 David Bloom QC Tax Avoidance: A View From the Dark Side (speech delivered at the Annual Tax Lecture, Melbourne Law School, 5 August 2015) at 22.

159 John Prebble and Hamish McIntosh "Predication: The Test for Tax Avoidance in New Zealand from Newton to Ben Nevis" (2015) 46 VUWLR 1011 at 1013.

160 Rebecca Prebble and John Prebble "Does the Use of General Anti-Avoidance Rules to Combat Tax Avoidance Breach Principles of the Rule of Law? A Comparative Study" (2010) 55 SLU 21 at 24. 
A judgement that a transaction is abusive, or tax benefit is inappropriate, requires a benchmark against which to test the appropriate tax to be collected in a legitimate or normal transaction of the relevant kind. The goal and effect of a GAAR is to subject a taxpayer, in respect of a specific structure or transaction, to more tax than would otherwise apply under the general statutory income tax rule. As it is impossible to identify in advance all of the ways in which tax law may be avoided, the GAAR also operates to deter tax avoidance activity. In this way the GAAR may assist governments to "combat the more creative forms of tax avoidance that employ transactions governments cannot predict". 161

What of the thorny relationship between a statutory GAAR, the "rule of law" and elusive certainty? ${ }^{162}$ Why are GAARs seen as so problematic? As Prebble and Prebble observe, all rules have a "penumbra" or margin of uncertainty at their borders; but arguably, GAARs "are nothing but penumbras". ${ }^{163}$ The concerns that they identify about GAARS are: their failure to provide "guidance" to people seeking to follow the law; effects on "liberty", especially, taxpayers not knowing what is the scope of action available to them (however, they are rightly sceptical about the extent to which GAARs really constrain taxpayer liberty); respect for human dignity and knowing what the law is; and the instrumental goal that the law should be actually effective and able to be followed.

Sham transactions exploit the formality of legal construction of transactions, including the evidentiary requirements needed to establish a transaction. However, tax avoidance in the words of Prebble and Prebble exploits the formality of tax law, and thereby "exploits the values of the rule of law". ${ }^{164}$ They also provocatively argue that: ${ }^{165}$

When general anti-avoidance rules are ineffective, this ineffectiveness is not due primarily to taxpayers

being inadequately guided. [...] it is because the judiciary does not know what to make of them.

Judging by the case law, on the whole, Australia's GAAR seems to be effective. The most difficult issues in application of the GAAR arise in its relationship with the various complex statutory regimes in the income tax law, and with TAARs. Now that the issue of a "null" counterfactual has been put to bed by the 2013 amendments, the most challenging issue for the GAAR is how to apply it to complex statutory regimes, such as the consolidated group regime. This interaction has left continued uncertainty about which taxpayer should be assessed, and how to ascertain an avoidance purpose for a "fictional" entity in the consolidation regime.

161 At 25 .

162 Prebble and Prebble, above n 160; and see also G Cooper Tax Avoidance and the Rule of Law (IBFD, The Netherlands, 1999)

163 Prebble and Prebble, above n 160, at 30.

164 At 45

165 At 37 
The location of TAARs in the GAAR (or at least, in pt IVA), is problematic. While the particular designation of pt IVA as the GAAR should not be overemphasised, in Australian tax "lore", "Part IVA" has taken on a certain symbolism. Despite their long history in pt IVA, s 177E and 177EA could be considered to sully the purity of the GAAR, one of whose virtues is its uniqueness and its general operation as an "integrated whole" across the extent of the income tax statute including tax treaties. The pre-existing TAARs in pt IVA also provide a precedent for the addition of new TAARs, specifically the MAAL and the DPT.

In the international context, the core aim of the rules is to allocate tax jurisdiction by establishing the right to tax in one country and the conditions for non-taxation or limited taxation by another country. It is generally considered that an anti-abuse rule in a treaty cannot, in itself, authorise a tax agency to levy more taxation. In contrast, the MAAL and DPT, together do authorise substantive taxing powers in the Commissioner. This seems to make these anti-avoidance rules into structural international tax rules extending jurisdiction. The MAAL is a makeshift assertion of market taxing rights, while the DPT asserts a jurisdiction to tax income which is, at least formally, not sourced in Australia nor derived by an Australian taxpayer. It is a bold jurisdictional claim, which echoes the claim to tax low-taxed accrual income controlled by Australian taxpayers under the CFC rules. Along with the presence of the "sufficient foreign tax" exception, the DPT might be a rudimentary implementation of the minimum tax approach in Inclusive Framework Pillar II. These two GAAR extensions can be taken together as heralding the new norms that the OECD is attempting to set in the Inclusive Framework Consensus of 2021. This leads to an important question that is directly relevant to current international tax negotiations: should the MAAL and DPT be repealed as part of the commitment to end unilateral measures under the Consensus Statement?

The GAAR is a necessary organic or foundational rule to protect the operation of the core income tax statute; to manage its relationship with economic reality. The GAAR secures its own legitimacy by ensuring its marginal rather than structural taxing character, limiting its scope of operation to setting the boundaries of appropriate behaviour under the income tax statute and managing its relation to economic reality. It may often be argued that, where an anti-abuse rule is applied, this is an indication of a flaw in the existing core structure that should be remedied with more general reform. In the international arena, fundamental reform to tax jurisdictional rules and a global minimum tax would be a better way to achieve certainty and legitimate, adequate taxation. 